\title{
SEBARAN DAN JENIS LAMUN PANTAI PANCURAN BELAKANG PULAU KARIMUNJAWA, TAMAN NASIONAL KARIMUNJAWA, JEPARA
}

\author{
Nabila Fikri Dwi Cahyani, Agus Hartoko ${ }^{1}$, Suryanti \\ Program Studi Manajemen Sumberdaya Perairan, Jurusan Perikanan \\ Fakultas Perikanan dan Ilmu Kelautan, Universitas Diponegoro
}

\begin{abstract}
ABSTRAK
Pantai Pancuran Belakang adalah salah satu pantai di Pulau Karimunjawa, Jepara, Jawa Tengah. Pulau Karimunjawa memiliki potensi sumberdaya alam pesisir yang besar. Pantai ini juga sebagai habitat lamun. Salah satu peran penting dari lamun adalah sebagai pendaur ulang zat hara.

Materi yang digunakan dalam penelitian ini adalah sedimen dasar perairan serta citra Satelit GeoEye tahun 2011. Metode yang digunakan adalah metode deskriptif dengan teknik pengambilan sampel secara acak. Pengambilan sampel dilakukan di sekitar Pantai Pancuran Belakang pada 2 stasiun yang berbeda. Masing-masing stasiun terdiri dari 9 plot dengan ukuran 10x10 m. Pada tiap plot dibagi menjadi subplot dengan ukuran 1x1 m, sehingga didapatkan 100 subplot. Dari 100 subplot tersebut kemudian dilakukan pengambilan sampel pada 5 subplot secara acak. Sampel sedimen kemudian dianalisa di Laboratorium Mekanika Tanah, Fakultas Teknik, Universitas Diponegoro.

Keragaman tekstur sedimen dasar perairan yang dimiliki mengakibatkan terjadinya pola sebaran lamun yang hidup di pantai tersebut. Setelah data didapatkan kemudian dilakukan pengolahan data yang terdiri dari kelimpahan/kerapatan, persentase tutupan, serta uji korelasi oleh software SPSS.

Hasil yang di dapatkan 8 jenis lamun yaitu Thalassia hemperichii, Cymodocea rotundata, Syringodium isoetifolium, Halophilla minor, Enhalus acroides, Halophila ovalis, Cymodocea serrulata dan Halodule pinifolia. Kerapatan tertinggi ditemukan pada Cymodocea rotundata yaitu 52,16\% atau total 505 individu. Sedangkan penutupan tertinggi terdapat pada jenis Cymodocea rotundata yaitu 6,565 m2. Terdapat 3 jenis substrat yaitu gravel, sand dan silt. Berdasarkan hasil perhitungan dengan menggunakan software SPSS di dapatkan nilai p sebesar 0,06 pada stasiun 1 dan 0,09 pada stasiun 2 . Hal tersebut menyatakan bahwa ada hubungan yang erat antara kerapatan lamun dengan persentase substrat pasir.
\end{abstract}

Kata Kunci : Lamun, Sebaran, Pantai Pancuran Belakang.

\section{ABSTRACT}

Pancuran Belakang Beach is one of the beaches on the Karimunjawa island, Jepara, Central Java. Karimunjawa island has a lot of coastal natural resources's potential. This beach also became an seagrass habitat. One of the important role of seagrass is as nutrient recycler.

The material used in this research were water sediments and the GeoEye satellite image of 2011. The method used is descriptive method with random sampling technique. Samples was carried out around the Pancuran Belakang Beach, Karimunjawa on 2 different stations. Each station consists of 9 plot with a size of $10 \times 10 \mathrm{~m}$. Each plot was divided into subplots with the size of 1x1 m, so it obtained 100 subplots. The sample was taken from 5 different subplots randomly. Sediment sample was analyzed in a Soil Mechanics laboratory, Faculty of Engineering, Diponegoro University.

The diversity of sediment texture leads to a pattern of Seagrass's distribution that lived on the coast. The analysis data consist of the seagrass's density, canopy percentage, and the correlation were accomplished using SPSS software.

The results of this research is founding 8 different seagrass species, there are Thalassia hemperichii, Cymodocea rotundata, Syringodium isoetifolium, Halophilla minor, Enhalus acroides, Halophila ovalis, Cymodocea serrulata and Halodule pinifolia. There are found 3 different substrat, which are gravel, sand and silt. The highest density seagrass is Cymodocea rotundata, is it was (52,16\% or 505 individuals totally). The highest canopy is Cymodocea rotundata it was $6.565 \mathrm{~m} 2$. Based on the calculations results by SPSS software got "P" value. 0.06 at station 1 and 0,09 at station 2. It is shown there is a relationship between the density of seagrass with sand substrat percentage.

Keywords : Seagrass, Distribution, Pancuran Belakang Beach. 


\section{A. Pendahuluan}

Lamun (seagrass) adalah tumbuhan berbunga (Angiospermae) yang termasuk tumbuhan berbiji satu (Monocotyledonae) yang mempunyai akar, rimpang (rhizome), daun, bunga dan buah. Lamun dapat dijumpai tumbuh dan berkembang baik di lingkungan perairan laut dangkal perairan tropis. Lamun juga dapat membentuk kelompok-kelompok kecil dari beberapa meter persegi sampai berupa padang yang sangat luas yang mencapai ratusan hektar sehingga disebut padang lamun. Padang lamun dapat berbentuk vegetasi tunggal yang disusun oleh satu jenis lamun atau vegetasi campuran yang disusun mulai dari 2-12 jenis lamun yang tumbuh (Kiswara, 2000).

Padang lamun memiliki peranan penting di perairan, sehingga kelestariannya perlu dijaga. Ekosistem padang lamun adalah penunjang bagi kehidupan laut dangkal, jika ekosistem ini rusak maka produktivitas perairan akan menurun. Berkaitan dengan hal tersebut, maka perlu dilakukan suatu penelitian dan pengecekan kembali terhadap kondisi padang lamun Karimunjawa yang dapat menjadi dasar dalam pengelolaan ekosistem padang lamun di perairan Karimunjawa.

Ekosistem padang lamun juga mempunyai peran dan fungsi sebagai daerah untuk mencari makanan (alimentasi), tempat berlindung bagi beberapa jenis organisme, daerah perangkap sedimen dan sebagai penopang hidup bagi organisme (Kikuchi dan Peres,1977).

Kawasan pesisir Indonesia memegang peranan penting, karena kawasa ini memiliki potensi sumberdaya alam yang disebut sumberdaya pesisir. Taman nasional karimunjawa terdiri atas 22 gugus kepulauan dan memiliki luasan kawasan sekitar $111.625 \mathrm{Ha}$, tercatat memiliki berbagai macam potensi dan keanekaragaman hayati antara lain memiliki kekayaan alam hayati yang beranekaragam dan merupakan rumah bagi terumbu karang, hutan bakau, hutan pantai, serta hampir 400 spesies fauna laut. Banyak potensi yang telah diketahui diantaranya ekosisitem terumbu karang, ekosistem mangrove, ekosistem lamun, potensi perikanan, potensi wisata bahari, dan potensi wilayah pesisir lainnya (Harianto, 2005).

Sedimen dasar perairan mempunyai peranan penting bagi kehidupan lamun. Ukuran sedimen berpengaruh dalam menentukan kemampuan sedimen tersebut menahan sirkulasi air. Tekstur sedimen menentukan keberadaan lamun, dimana sedimen merupakan tempat untuk hidup. Menurut Dahuri (2001), sedimen yang terdiri dari lumpur, pasir, kerikil, lempung dan liat merupakan substrat yang dapat ditumbuhi lamun. Lamun dapat hidup diberbagai jenis sedimen yang dimulai dari lumpur hingga sedimen dasar yang 40 persen merupakan endapan lumpur.

Tujuan dari penelitian ini adalah untuk mengetahui jenis-jenis lamun yang ditemukan di Perairan Pantai Pancuran Belakang T.N Karimunjawa, mengetahui kerapatan, persentase tutupan lamun di Perairan Pantai Pancuran Belakang T.N Karimunjawa; dan mengetahui pengaruh jenis sedimen terhadap kerapatan lamun di Pantai Pancuran Belakang, T.N Karimunjawa. Hasil dari kegiatan penelitian ini diharapkan dapat memberikan informasi mengenai jenis lamun, jenis sedimen terhadap sebaran lamun di Pantai Pancuran Belakang Pulau Karimunjawa, Taman Nasional Karimunjawa. Selanjutnya informasi ini dapat digunakan sebagai salah satu pertimbangan dalam upaya pengelolaan jangka panjang untuk sumberdaya lamun tersebut.

\section{B. Materi dan Metode Penelitian}

1. Alat

Alat yang digunakan dalam penelitian di lapangan ini adalah kuadran transek sebanyak 3 buah digunakan untuk membatasi bidang pengamatan, rol meter $50 \mathrm{~m}$ untuk mengukur petak sampel (plot), masker, snorkle, kamera underwater digunakan untuk mendokumentasikan kegiatan, GPS (Global Positioning System) untuk menentukan lokasi titik sampling, kuadran transek 1m x 1m sebanyak 2 buah, bola arus digunakan untuk mengukur arus air, papan dan pensil digunakan untuk mencatat data sampling, termometer 2 buah untuk mengukur suhu air dan suhu udara, $\mathrm{pH}$ paper digunakan untuk mengetahui $\mathrm{pH}$ perairan, salinometer digunakan untuk mengukur salinitas perairan, kantong plastik digunakan sebagai tempat sampel substrat, cetok digunakan untuk mengambil substrat, buku identifikasi lamun untuk menentukan jenis lamun dan kamera digital untuk mendokumentasikan kegiatan penelitian. Sedangkan alat yang digunakan untuk pengolahan data adalah perangkat komputer, Software ER-Mapper untuk mengolah basis data, Software Microsoft Excel 2007 untuk mengolah data lapangan.

\section{Materi Penelitian}

Materi yang digunakan dalam penelitian ini adalah sampel jenis lamun dan sedimen untuk analisis jenis substrat dasar perairan, lamun yang berada di Pantai Pancuran Belakang, Pulau Karimunjawa sebagai objek yang diteliti, data satelit GeoEye Pulau Karimunjawa tahun 2011 untuk analisis peta persebaran lamun, akuades untuk kalibrasi salinometer.

\section{Metode Penelitian}

Metode yang digunakan pada penelitian ini adalah metode observasi langsung, dimana metode ini bersifat studi kasus (case study) yang menggambarkan secara sistematis, faktual dan akurat mengenai faktafakta, sifat-sifat, hubungan antara fenomena, atau peristiwa yang diselidiki pada masa sekarang. 


\section{Sampling dan Pengumpulan Data}

Penentuan lokasi sampling dibagi menjadi 2 stasiun dimana setiap stasiun dibagi menjadi tiga substasiun, berdasarkan pada perbedaan lokasi tiap stasiun yakni di Perairan Pantai Pancuran Belakang.

Penelitian ini dilakukan di Pantai Pancuran Belakang, Pulau Karimunjawa dengan jumlah lokasi titik pengambilan sampel sebanyak 2 stasiun. Masing-masing stasiun terdiri dari 9 plot dan masing-masing plot terdiri dari 5 titik sampel.

Selain itu posisi titik sampling (Ground Control Point) dicatat menggunakan Global Positioning System (GPS) melalui posisi lintang dan bujurnya (Hariadi, 2006 dalam Abroni, 2012).

\section{Metode Pengambilan Sampel}

Pengambilan sampel pada tiap titik subplot menggunakan metode sampling acak. Metode sampling acak adalah teknik penentuan sampel dengan pertimbangan tertentu (Sugiyono, 2011).

Pengambilan sampel sedimen dengan cara mengambil sebagian sedimen dari tiap plot kemudian dimasukan kedalam kantong plastik. Pengukuran suhu dengan termometer air raksa dan pengukuran salinitas dengan menggunakan salinometer (Boehlert and Mundy, 1988 dalam Abroni, 2012).

\section{Pengolahan Data}

Jenis data yang diperlukan terdiri dari data primer yang meliputi data lamun (jenis, persentase penutupan, frekuensi dan kerapatan lamun), sedangkan data sekunder meliputi keadaan umum lokasi penelitian. Data yang sudah didapatkan kemudian dihitung dengan rumus sebagai berikut :

a. Kerapatan Jenis (Di) \& Kerapatan Relatif (RDi)

$\mathrm{Di}=\frac{N i}{A}$

Keterangan : Di = Jumlah individu (tegakan) ke-i per satuan luas

$\mathrm{Ni} \quad=$ Jumlah individu (tegakan) ke-i dalam transek kuadrat

$\mathrm{A} \quad=$ Luas transek kuadrat

$\mathrm{RDi}=\frac{N i}{\sum_{i=1}^{P} n i j}$

Keterangan : RDi

$$
\begin{array}{ll}
\mathrm{Ni} & =\text { Jumlah individu (tegakan) ke-i dalam transek kuadrat } \\
\sum_{i=1}^{p} n i j & =\text { Jumlah seluruh spesies }
\end{array}
$$

b. $\quad$ Frekuensi Jenis (Fi) \& Frekuensi relatif (RFi)

$$
\begin{array}{rlrl} 
& \mathrm{Fi}=\frac{P i}{\sum_{i=1}^{P} P} & \\
\text { Keterangan : } \mathrm{Fi} & & =\text { Frekuensi jenis ke-i } \\
\mathrm{Pi} & & =\text { Jumlah petak contoh dimana ditemukan jenis ke-i } \\
\sum_{i=1}^{p} F i & & \\
\mathrm{RFi}=\frac{F i}{\sum_{i=1}^{P} F i} & \\
\text { Keterangan }: \mathrm{RFi} & =\text { Jumlah total petak contoh yang diamati } \\
\sum_{i=1}^{p} F i & =\text { Jumlah frekuensi seluruh spesies }
\end{array}
$$

c. Penutupan (Ci) \& Penutupan relatif (RCi)

$$
\mathrm{Ci}=\frac{\Sigma(M i x f i)}{\Sigma f}
$$

Keterangan $: \mathrm{Ci}=$ Persentase penutupan lamun

$\mathrm{Mi}=$ Persentase titik tengah dari kehadiran jenis lamun

$\boldsymbol{\Sigma} \mathrm{f}=$ Luas total pengambilan contoh

$\mathrm{RCi}=\frac{C i}{\Sigma C i}$

Keterangan: $\mathrm{RCi}=$ Penutupan Relatif

$\mathrm{Ci}=$ Luas area yang tertutupi spesies ke-i

$\boldsymbol{\Sigma} \mathrm{Ci}=$ Penutupan seluruh spesies

d. Indeks Nilai Penting (INP)

$\mathrm{INP}=\mathrm{RFi}+\mathrm{RDi}+\mathrm{RCi}$ 
Keterangan : RFi $=$ Frekuensi relatif

$\mathrm{RDi}=$ Kerapatan relatif

$\mathrm{RCi}=$ Penutupan relatif

e. Indeks Keanekaragaman (H') \& Indeks Keseragaman (e)

Perhitungan Indeks keanekaragaman Shannon-Wienner, yaitu:

$\mathrm{H}^{\prime}=\log \mathrm{N}-\frac{1}{\mathrm{~N}} \sum \mathrm{ni} \log \mathrm{ni}$

Keterangan: $\mathrm{H}^{\prime}$ = Indeks keanekaragaman Shannon-Wienner

$\mathrm{N}=$ Jumlah total spesies

$\mathrm{ni}=$ Jumlah individu tiap spesies ke-i

Klasifikasi indeks keanekaragaman Shannon-Wienner adalah sebagai berikut:

$$
\begin{array}{ll}
\mathrm{H}^{\prime}<1 & =\text { Indeks keanekaragaman rendah } \\
1 \leq \mathrm{H}^{\prime} \leq 3 & =\text { Indeks keanekaragaman sedang } \\
\mathrm{H}^{\prime}>3 & =\text { Indeks keanekaragaman tinggi }
\end{array}
$$

$\mathrm{e}=\frac{\mathrm{H} v}{\ln \mathrm{S}}$

Keterangan: $\mathrm{e} \quad=$ Indeks keseragaman

$\mathrm{H}^{\prime} \quad=$ Indeks keanekaragaman Shannon-Wienner

$\mathrm{S} \quad=$ Jumlah spesies

Menurut Krebs (1989) dalam Ariyanto (2011), indeks keseragaman berkisar antara 0-1, dimana:

$$
\begin{array}{ll}
0,6-1 & =\text { Keseragaman spesies tinggi } \\
0,4<\mathrm{e}<0,6 & =\text { Keseragaman spesies sedang } \\
0-0,4 & =\text { Keseragaman spesies rendah }
\end{array}
$$

\section{Pengolahan Data Citra Satelit GeoEye}

Pengolahan data berupa data posisi lintang dan bujur diolah dengan menggunakan software ER Mapper 7.0 untuk mengetahui sebaran spasial lamun di perairan pantai Pancuran Belakang. Berikut tahapan dalam pengolahan data citra menurut :

1. Analisa Kriging (Geo-Statistik) (Hartoko, 2008)

Mengubah dari data titik atau koordinat menjadi data spasial.

Tahapan prosedur pengolahan data yang dilakukan yaitu sebagai berikut:

a. Plotting titik koordinat

Plotting titik koordinat bertujuan untuk mengetahui lokasi penangkapan serta mengubah format titik koordinat yang didapat dari GPS (Derajat, Menit, Detik) menjadi derajat desimal, karena pada pengolahan selanjutnya di software ER-Mapper 7.0, harus menggunakan titik koordinat dengan format derajat desimal. Proses plotting ini menggunakan Microsoft excel dengan rumus

Numerik $=$. Derajat $+(($ Menit+(detik/60)/60) sedangkan untuk lintang selatan formula yang ada tersebut dikalikan dengan $(-1)$.

b. Gridding

Gridding bertujuan untuk mengetahui sebaran titik koordinat beserta sebaran lamun. Data yang digunakan pada proses gridding ini adalah titik koordinat (derajat desimal) dengan data lapangan sebaran lamun hingga proses pembuatan layout menggunakan software ER-Mapper 7.

c. Cropping (Pemotongan citra)

Pemotongan citra bertujuan untuk menyesuaikan ukuran citra dan membatasi wilayah pengamatan dengan objek yang akan dikaji. Data satelit Geoeye dipotong sesuai dengan lokasi penelitian yaitu wilayah perairan Pantai Pancuran Belakang, P. Karimunjawa, Kab. Jepara.

d. Overlay

Overlay dilakukan dengan membandingkan kedua data yang ada dan telah diolah. Tujuan dilakukan overlay untuk melihat apakah ada suatu perubahan atau perbedaaan antara data satu dengan data yang lainnya.

e. Pembuatan layout

Pembuatan layout peta hasil pengolahan data yang dilakukan pada software ER Mapper 7 bertujuan untuk memperjelas dan memberi tampilan peta beserta data-data yang tercakup di dalamnya. Hasil yang didapat kemudian ditampilkan dalam bentuk peta sebarannya.

\section{Hipotesis Penelitian}

Berdasarkan pada rumusan masalah maka hipotesis yang akan diajukan, yaitu:

Hubungan antara kerapatan lamun dengan substrat

$\mathrm{H}_{0}$ : Terdapat hubungan antara kerapatan lamun dengan substrat

$\mathrm{H}_{1}$ : Tidak ada hubungan antara kerapatan lamun dengan substrat

Kaidah pengambilan keputusannya adalah sebagai berikut :

Jika probabilitas $<0,05$ maka tidak terdapat hubungan antara kerapatan lamun dengan substrat 
Jika probabilitas $\geq 0,05$ maka terdapat hubungan antara kerapatan lamun dengan substrat

Untuk menguji hipotesis dalam penelitian, maka digunakan analisis korelasi Pearson. Menurut Suliyanto (2012), analisis korelasi merupakan salah satu teknik statistik yang digunakan untuk menganalisis hubungan antara dua variabel atau lebih bersifat kuantitatif. Uji korelasi menggunakan software SPSS, sedangkan untuk menggambarkan bentuk hubungan (pola/grafik) persamaan regresi menggunakan bantuan Microsoft excel 2007, maka akan didapatkan nilai koefisien korelasi (r) dan koefisien determinasi.

Menurut Hadi (2004), koefisien korelasi selalu bergerak diantara $-1 \geq r \leq 1$. Koefisien korelasi antara 0 sampai +1 menunjukkan korelasi yang positif sedangkan dari -1 sampai 0 menunjukkan korelasi yang negatif.

Tabel 1. Klasifikasi Nilai Koefisien Korelasi

\begin{tabular}{cc}
\hline Koefisien Korelasi $(\mathbf{r})$ & Interpretasi \\
\hline $0,8-1$ & Tinggi \\
$0,6-0,8$ & Cukup tinggi \\
$0,4-0,6$ & Agak rendah \\
$0,2-0,4$ & Rendah \\
$0,0-0,2$ & Sangat rendah (Tak berkorelasi) \\
\hline
\end{tabular}

Sumber : Hadi (2004)

Analisa regresi yang dilakukan yaitu regresi tunggal (single regression). Regresi tunggal ini dilakukan dengan menghubungkan persentase substrat dengan kerapatan lamun. Analisis regresi ini dilakukan untuk mengetahui apakah kerapatan lamun dipengaruhi oleh persentase substrat atau tidak. Regresi ini menggunakan persamaan polinomial yaitu $\mathrm{Y}=\mathrm{a}+\mathrm{bx}+\mathrm{cx}^{2}$ dimana:

$\mathrm{Y} \quad=$ variabel terikat (kerapatan lamun)

$\mathrm{X} \quad=$ variabel bebas (persentase substrat)

a $\quad$ constant

$\mathrm{b}, \mathrm{c} \quad=$ koefisien

\section{Hasil dan Pembahasan}

1. Hasil

a. Gambaran Umum Lokasi Penelitian

Taman Nasional Karimunjawa menurut Keputusan Mentri Kehutanan No. 161/ Kpts-II/ 1986 tanggal 9 April 1986 dikukuhkan sebagai Cagar Alam dan keputusan Mentri Kehutanan No. 78/ Kpts-II/1999 tanggal 22 Februari 1999 ditetapkan perubahan fungsi Cagar Alam Karimunjawa menjadi Taman Nasional Karimunjawa. Tahun 2001 sebagian luas kawasan TN Karimunjawa seluas 110.117,30 Ha ditetapkan sebagai Kawasan Pelestarian Alam Perairan dengan keputusan Menhut No. 74/Kpts-II/2001. Taman Nasional Karimunjawa secara administratif termasuk wilayah Kabupaten Jepara, Provinsi Jawa Tengah yang memiliki letak geografis $5^{0} 42^{\prime}-6^{\circ} 00^{\prime} \mathrm{LS}$ dan $110^{\circ} 07^{\prime}-110^{\circ} 37^{\prime} \mathrm{BT}$ dengan luas keseluruhan 111.625 Ha dan temperatur udara sekitar $23^{0}-32^{0} \mathrm{C}$ dengan ketinggian tempat $0-605$ meter dpl yang meliputi 22 pulau yang mempunyai ekosistem asli dengan keanekaragaman hayati yang tinggi mulai dari daratan hingga perairannya yang perlu dipertahankan dan dimanfaatkan secara lestari dan bijaksana ( BTNKJ, 2012 ).

Pulau Karimunjawa merupakan salah satu pulau besar yang terletak pada koordinat $5^{0} 50^{\prime} 08^{\prime \prime}-5^{0} 53^{\prime} 25$, LS dan $110^{\circ} 26^{\prime} 15^{\prime \prime}-110^{\circ} 26^{\prime} 55^{\prime \prime}$ BT dengan luas daratan 4302,5 Ha. Pulau ini beriklim tropis yang dipengaruhi oleh angin laut yang bertiup sepanjang hari dengan suhu rata-rata $26-30{ }^{\circ} \mathrm{C}$. Sebagai pulau besar yang berpenghuni, banyak aktivitas kompleks yang sangat memungkinkan terganggunya kondisi perairan disekitar pulau Karimunjawa terpengaruh oleh berbagai aktivitas di pulau tersebut ( BTNKJ, 2012 ).

b. Jenis-jenis Lamun yang Ditemukan

Jenis lamun yang ditemukan di lokasi penelitian dicocokan dengan melihat referensi identifikasi lamun menurut Field Guide to the Identification of East Asian WESTPAC (2010). Pengamatan dilakukan dengan melihat bentuk daun lamun. Jenis lamun yang ditemui di kedua stasiun disajikan pada Tabel berikut:

Tabel 2 . Jenis-jenis Lamun yang Ditemukan pada masing-masing Stasiun

\begin{tabular}{cccc}
\hline No & Jenis & Stasiun 1 & Stasiun 2 \\
\hline 1 & Thalassia hemperichii & $\sqrt{ }$ & $\sqrt{ }$ \\
2 & Cymodocea rotundata & $\sqrt{ }$ & $\sqrt{ }$ \\
3 & Syringodium isoetifolium & $\sqrt{ }$ & $\sqrt{ }$ \\
4 & Halophilla minor & $\sqrt{ }$ & $\sqrt{ }$ \\
5 & Enhalus acroides & $\sqrt{ }$ & $\sqrt{ }$ \\
6 & Halophila ovalis & - & $\sqrt{ }$ \\
7 & Cymodocea serrulata & - & $\sqrt{ }$ \\
8 & Halodule pinifolia & - & \\
\hline
\end{tabular}

Sumber : Hasil Penelitian (2013) 
c. Persentase Tutupan

Hasil persentase tutupan padang lamun di dua stasiun pengamatan Perairan Pantai Pancuran Belakang, TN Karimunjawa di sajikan pada Tabel berikut:

Tabel 3. Penutupan (Ci) dan Penutupan Relatif (RCi))

\begin{tabular}{|c|c|c|c|c|c|}
\hline \multirow[b]{2}{*}{ No } & \multirow[b]{2}{*}{ Jenis } & \multicolumn{2}{|c|}{ Stasiun 1} & \multicolumn{2}{|c|}{ Stasiun 2} \\
\hline & & $\begin{array}{c}\mathrm{Ci} \\
\text { (individu) }\end{array}$ & $\begin{array}{l}\mathrm{RCi} \\
(\%)\end{array}$ & $\begin{array}{c}\mathrm{Ci} \\
\text { (individu) }\end{array}$ & $\begin{array}{l}\mathrm{RCi} \\
(\%)\end{array}$ \\
\hline 1 & Thalassia hemperichii & 1790 & 22.7128537 & 2980 & 25.183808 \\
\hline 2 & Cymodocea rotundata & 4667 & 59.2183733 & 6565 & 55.4804361 \\
\hline 3 & Syringodium isoetifolium & 900 & 11.41987057 & 1350 & 11.4087721 \\
\hline 4 & Halophilla minor & 80 & 1.015099607 & 168 & 1.4197583 \\
\hline 5 & Enhalus acroides & 384 & 4.872478112 & 624 & 5.27338798 \\
\hline 6 & Halophila ovalis & 60 & 0.761324705 & 100 & 0.84509423 \\
\hline 7 & Cymodocea serrulata & 0 & 0 & 40 & 0.33803769 \\
\hline 8 & Halodule pinifolia & 0 & 0 & 6 & 0.05070565 \\
\hline & Jumlah & 7881 & 100 & 11833 & 100 \\
\hline
\end{tabular}

Sumber : Hasil Penelitian (2013)

\section{d. Kerapatan Lamun}

Berdasarkan hasil pengamatan kerapatan dan kerapatan relatif lamun dapat dilihat pada Tabel berikut:

Tabel 4. Kerapatan Jenis (Di) dan Kerapatan Relatif (RDi) Lamun

\begin{tabular}{cccccc}
\hline \multirow{2}{*}{ No } & Jenis & \multicolumn{3}{c}{ Stasiun 1 } & \multicolumn{2}{c}{ Stasiun 2 } \\
\cline { 3 - 6 } & & $\begin{array}{c}\mathrm{Di} \\
\text { (individu) }\end{array}$ & $\begin{array}{c}\mathrm{RDi} \\
(\%)\end{array}$ & $\begin{array}{c}\text { Di } \\
\text { (individu) }\end{array}$ & $\begin{array}{c}\text { RDi } \\
(\%)\end{array}$ \\
\hline 1 & Thalassia hemperichii & 179 & 28.18897638 & 298 & 30.785124 \\
2 & Cymodocea rotundata & 359 & 56.53543307 & 505 & 52.1694215 \\
3 & Syringodium isoetifolium & 60 & 9.448818898 & 90 & 9.29752066 \\
4 & Halophilla minor & 10 & 1.57480315 & 21 & 2.16942149 \\
5 & Enhalus acroides & 24 & 3.779527559 & 39 & 4.02892562 \\
6 & Halophila ovalis & 3 & 0.472440945 & 5 & 0.51652893 \\
7 & Cymodocea serrulata & 0 & 0 & 4 & 0.41322314 \\
8 & Halodule pinifolia & 0 & 0 & 6 & 0.61983471 \\
\hline
\end{tabular}

Sumber : Hasil Penelitian (2013)

\section{e. Frekuensi}

Nilai frekuensi jenis dan frekuensi relatif lamun dapat dilihat pada tabel berikut :

Tabel 5 . Frekuensi Jenis (Fi) dan Frekuensi Relatif (RFi) Lamun

\begin{tabular}{llcccc}
\hline \multirow{2}{*}{ No } & \multirow{2}{*}{ Jenis } & \multicolumn{2}{c}{ Stasiun 1 } & \multicolumn{2}{c}{ Stasiun 2 } \\
\cline { 3 - 6 } & & $\begin{array}{c}\text { Fi } \\
\text { (individu) }\end{array}$ & $\begin{array}{c}\text { Rfi } \\
(\%)\end{array}$ & $\begin{array}{c}\text { Fi } \\
\text { (individu) }\end{array}$ & $\begin{array}{c}\text { RFi } \\
(\%)\end{array}$ \\
\hline 1 & Thalassia hemperichii & 26 & 24.29906542 & 51 & 24.8780488 \\
2 & Cymodocea rotundata & 35 & 32.71028037 & 70 & 34.1463415 \\
3 & Syringodium isoetifolium & 20 & 18.69158879 & 42 & 20.4878049 \\
4 & Halophilla minor & 7 & 6.542056075 & 9 & 4.3902439 \\
5 & Enhalus acroides & 18 & 16.82242991 & 20 & 9.75609756 \\
6 & Halophila ovalis & 1 & 0.934579439 & 8 & 3.90243902 \\
7 & Cymodocea serrulata & 0 & 0 & 3 & 1.46341463 \\
8 & Halodule pinifolia & 0 & 0 & 2 & 0.97560976 \\
\hline \multicolumn{2}{r}{ Jumlah } & 107 & 100 & 205 & 100 \\
\hline
\end{tabular}

Sumber : Hasil Penelitian (2013) 


\section{f. Indeks Nilai Penting (INP)}

Indeks nilai penting tumbuhan lamun di perairan Pantai Pancuran Belakang dapat dilihat pada table berikut.

Tabel 6. Indeks Nilai Penting (INP)

\begin{tabular}{llrr}
\hline No & \multicolumn{1}{c}{ Jenis } & $\begin{array}{c}\text { Stasiun } 1 \\
(\%)\end{array}$ & $\begin{array}{c}\text { Stasiun } 2 \\
(\%)\end{array}$ \\
\hline 1 & Thalassia hemperichii & 75.2008955 & 80.84698074 \\
2 & Cymodocea rotundata & 148.464087 & 141.796199 \\
3 & Syringodium isoetifolium & 39.5602783 & 41.19409762 \\
4 & Halophilla minor & 9.13195883 & 7.979423693 \\
5 & Enhalus acroides & 25.4744356 & 19.05841116 \\
6 & Halophila ovalis & 2.16834509 & 5.264062178 \\
7 & Cymodocea serrulata & 0 & 2.214675466 \\
8 & Halodule pinifolia & 0 & 1.646150121 \\
\hline \multicolumn{2}{r}{ Jumlah } & 300 & 300 \\
\hline
\end{tabular}

Sumber : Hasil Penelitian (2013)

g. Indeks Keanekaragaman dan Indeks Keseragaman

Hasil indeks keanekaragaman dan indeks keseragaman lamun dapat dilihat pada Tabel berikut:

Tabel 7. Indeks Keanekaragaman dan Indeks Keseragaman Lamun

\begin{tabular}{ccc}
\hline Stasiun Pengamatan & $\mathrm{H}^{\prime}$ & $\mathrm{E}$ \\
\hline Stasiun 1 & 1,09 & 0.183 \\
Stasiun 2 & 0,84 & 0.106 \\
\hline Jumlah Keseluruhan & 1,93 & 0,289 \\
\hline
\end{tabular}

Sumber : Hasil Penelitian( 2013)

h. Pengolahan Data Satelit

Analisa sebaran lamun dengan menggunakan metode Kriging (Hartoko, 2008) menghasilkan peta sebaran lamun seperti pada gambar berikut:
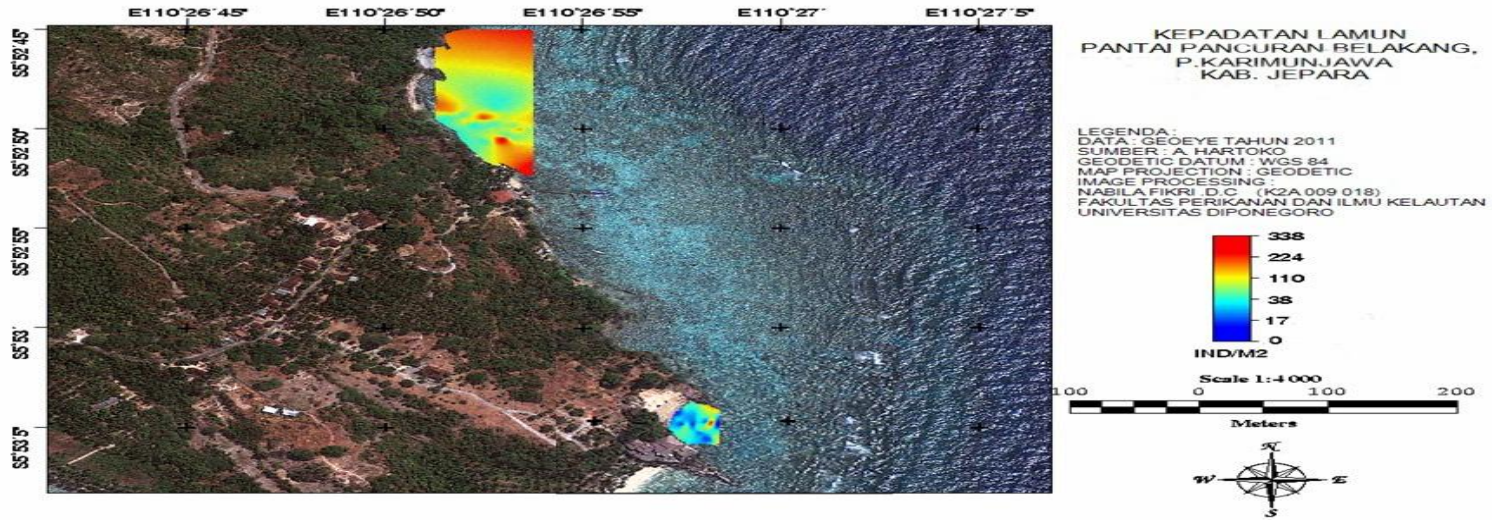

Gambar 1. Kepadatan Lamun (ind $/ \mathrm{m}^{2}$ ) di Pantai Pancuran Belakang TN Karimunjawa Jepara pada stasiun 1 dan 2.
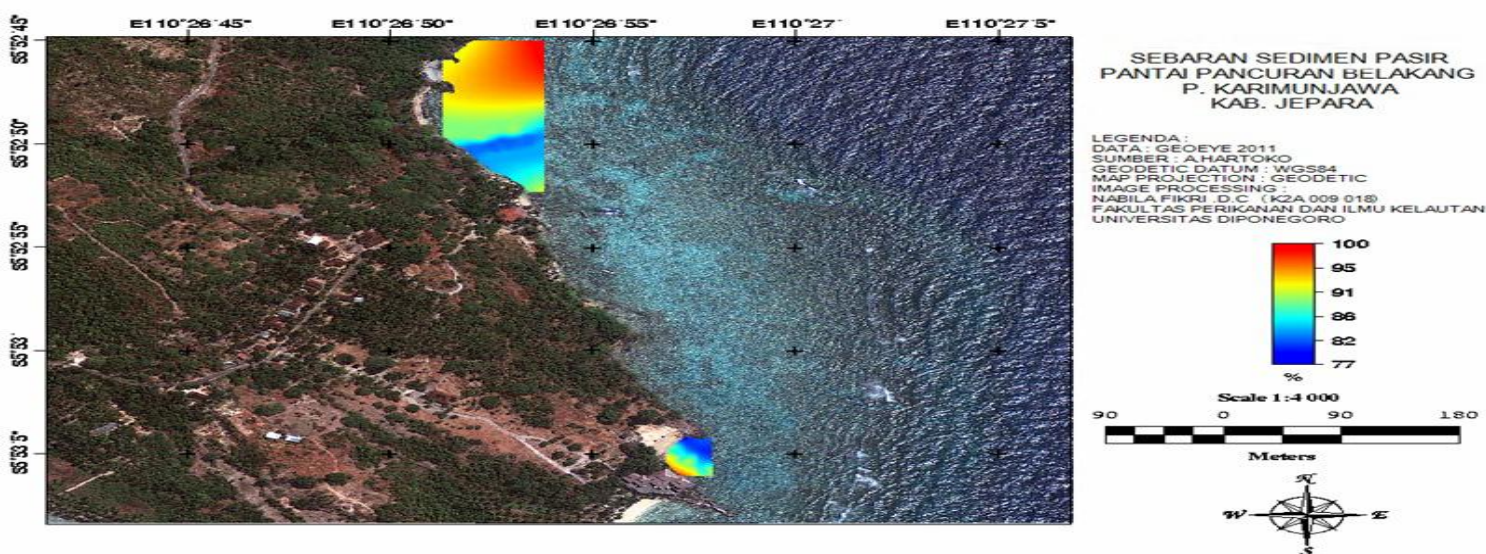

Gambar 2. Peta sebaran sedimen Pasir (\%) pada Stasiun 1 dan stasiun 2 di Pantai Pancuran Belakang 
i. Korelasi antara Kerapatan Lamun dengan Persentase substrat

Uji korelasi menggunakan Microsoft Excel 2007, dan untuk melihat bentuk hubungan (pola/grafik) persamaan regresi menggunakan Microsoft excel 2007, sedangkan untuk melihat probabilitasnya digunakan software SPSS.

\section{j. Korelasi antara Sebaran Lamun dan Persentase substrat Sand}

Nilai korelasi antara kerapatan lamun dengan kandungan sand pada stasiun 1 diperoleh nilai 0,9828 yang berarti hubungan diantara keduanya kuat dan searah, artinya semakin besar persentase substrat akan semakin besar pula persentase kerapatan lamun. Nilai koefisien determinasi $\left(\mathrm{R}^{2}\right)$ yang diperoleh $0,966(96,6 \%)$, koefisien determinasi menunjukan hampir 96,6\% kerapatan lamun dipengaruhi oleh persentase sand dan $3,4 \%$ oleh pengaruh dari luar. Persamaan koefisien determinasi menunjukkan $7,447 x^{2}-1241 x+5,176$. Nilai signifikasi diperoleh 0,006 yang berarti terdapat pengaruh hubungan antara kepadatan lamun dengan substrat sand.

Nilai korelasi antara kerapatan lamun dengan kandungan sand pada stasiun 2 diperoleh nilai 0,9823. Nilai koefisien determinasi $\left(\mathrm{R}^{2}\right)$ yang diperoleh 0,965 (96,5\%), koefisien determinasi menunjukan hampir $92 \%$ kerapatan lamun dipengaruhi oleh persentase sand dan 3,5\% oleh pengaruh dari luar. Persamaan koefisien determinasi menunjukkan $5,019 \mathrm{x}^{2}-902,4 \mathrm{x}+4,0584$. Nilai signifikasi diperoleh 0,009 yang berarti terdapat pengaruh substrat sand terhadap kerapatan lamun.

\section{k. Hasil Parameter Fisika dan Kimia}

Hasil pengukuran nilai parameter fisika dan kimia perairan pada saat dilakukannya penelitian dapat dilihat pada Tabel berikut:

Tabel 8. Parameter Fisika dan Kimia

\begin{tabular}{llcc}
\hline No & \multicolumn{1}{c}{ Parameter } & Stasiun 1 & Stasiun 2 \\
\hline & Fisika & & \\
1 & Suhu Air $\left({ }^{0} \mathrm{C}\right)$ & 31 & 32 \\
2 & Suhu Udara $\left({ }^{0} \mathrm{C}\right)$ & 29 & 28 \\
3 & Kecepatan arus & 0,06 & 0,04 \\
4 & Kedalaman (cm) & $30-140$ & $30-147$ \\
& Kimia & & \\
5 & pH & 8 & 33 \\
6 & Salinitas $(\%)$ & 33 & 33 \\
\hline
\end{tabular}

Sumber : Hasil Penelitian (2013)

\section{l. Karakteristik Substrat}

Berdasarkan hasil analisa substrat yang dilakukan di Laboratorium Mekanika Tanah, Fakultas Teknik Universitas Diponegoro di dapatkan karakteristik substrat pada kedua stasiun yakni pada Tabel berikut: Tabel 9. Karakteristik Substrat

\begin{tabular}{lllllll}
\hline \multirow{2}{*}{ Tipe } & \multicolumn{3}{c}{ Stasiun 1 } & \multicolumn{3}{c}{ Stasiun 2 } \\
\cline { 2 - 7 } & \multicolumn{1}{c}{1.1} & \multicolumn{1}{c}{1.2.} & \multicolumn{1}{c}{1.3} & \multicolumn{1}{c}{2.1} & \multicolumn{1}{c}{2.2} & 2.3 \\
\hline Gravel (Batu/ Pecahan Karang) & $9 \%$ & $16.75 \%$ & $17.80 \%$ & $17.80 \%$ & $12.70 \%$ & $8 \%$ \\
Sand (Pasir) & $89.05 \%$ & $82.30 \%$ & $83.50 \%$ & $81.20 \%$ & $87.30 \%$ & $90.20 \%$ \\
Silt (Lanau/Endapan Lumpur) & $1.95 \%$ & $1 \%$ & $4.70 \%$ & $1 \%$ & $0 \%$ & $1.80 \%$ \\
Clay (Lempung) & $0 \%$ & $0 \%$ & $0 \%$ & $0 \%$ & $0 \%$ & $0 \%$ \\
\hline
\end{tabular}

Sumber : Hasil Penelitian (2013)

\section{Pembahasan}

\section{a. Jenis Lamun yang ditemukan dan Sebaran Lamun}

Berdasarkan hasil penelitian yang dilakukan di kedua stasiun pengamatan jumlah dan jenis lamun yang ditemukan berbeda. Jenis lamun terbanyak yang ditemukan yakni pada stasiun 2 sebanyak 8 spesies, sedangkan pada stasiun 1 hanya ditemukan 6 spesies saja. Stasiun 1 lamun yang ditemukan Thalassia hemperichii, Cymodocea rotundata, Syringodium isoetifolium, Halophilla minor, Enhalus acroides, dan Halophila ovalis. Pada stasiun 2 jenis lamun yang ditemukan antara lain Thalassia hemperichii, Cymodocea rotundata, Syringodium isoetifolium, Halophilla minor, Enhalus acroides, dan Halophila ovalis, Cymodocea serrulata dan Halodule pinifolia. Jenis yang paling sering di temukan pada stasiun 1 dan 2 berturut-turut adalah Cymodocea rotundata. Halodule pinifolia merupakan jenis lamun yang paling sedikit ditemui dari kedua stasiun yang diamati.

Kecepatan arus pada stasiun 1 dan 2 masing-masing 0,06 dan 0,04 m/s. Kecepatan arus di perairan akan mempengaruhi melekatnya spora. Menurut Aslan (1998), kebanyakan spora bersifat planktonis, sehingga sebarannya tersebut dipengaruhi arus. Arus yang lebih kuat akan menggerakkan massa air lebih besar, sehingga dapat mencapai area yang lebih luas. Gerakan air ini akan membawa spora makro alga yang bersifat planktonis tumbuh menyebar di perairan, dengan didukung arus yang stabil maka spora tersebut akan melekat pada substrat yang sesuai untuk tumbuh. 
Stasiun 2 kondisi lingkungannya lebih alami, kondisinya belum tercemar oleh aktivitas masyarakat sekitar serta kondisi perairan yang relatif tenang serta sinar matahari yang masuk juga cukup banyak, sedangkan pada stasiun 1 kondisi perairannya tidak sealami stasiun 2. Kondisi perairan stasiun 2 dipengaruhi oleh kegiatan masyarakat sekitar yang kurang ramah lingkungan seperti membuang sampah secara sembarangan yang menjadikan kondisi perairan dan lingkungan terganggu sehingga mempengaruhi ekosistem lamun yang ada disana. Hal ini menunjukan kerapatan jenis lamun akan semakin tinggi jika kondisi lingkungan tumbuhnya lamun dalam keadaan baik. Menurut Kiswara (2004), kerapatan jenis lamun dipengaruhi faktor tumbuh lamun tersebut. Beberapa faktor yang mempengaruhi kerapatan jenis lamun diantaranya adalah kedalaman, kecerahan, arus air dan tipe substrat.

Perairan Pantai Pancuran Belakang, Pulau Karimunjawa, TN Karimunjawa padang lamun tumbuh lebih dari 1 jenis (6 sampai 8 spesies) karena perairan ini termasuk dalam perairan tropis. Penyebaran lamun sangat bervariasi tergantung pola topografi pantai dan pola pasang surut. Menurut Azkab (2006), untuk perairan tropis seperti Indonesia padang lamun lebih dominan tumbuh dengan koloni yang terdiri dari beberapa jenis (mix species) pada suatu kawasan tertentu. Berbeda dengan kawasan daerah dingin yang kebanyakan di dominasi satu jenis lamun saja (single species).

\section{b. Persentase Tutupan}

Kerapatan relatif, frekuensi relatif dan penutupan relatif di hitung untuk mencari nilai Indeks Nilai Penting (INP) yang menggambarkan peranan suatu spesies lamun terhadap spesies lainnya dalam suatu komunitas. Hasil yang di dapatkan jenis lamun yang memiliki peranan tinggi dalam komunitasnya yakni Thalassia hemperichii, Cymodocea rotundata dan Syringodium isoetifolium. Ketiga jenis ini paling dominan ada pada kedua stasiun yang diamati, sedangkan Cymodocea serrulata dan Halodule pinifolia menurupakan jenis yang paling rendah, karena dilihat dari nilai kerapatan dan kemunculannya hanya berada di stasiun 2 saja. Hal ini sesuai dengan refrensi menurut Romimohtarto (2001) bahwa lamun jenis Thalassia hempricii mampu tumbuh dan berkembang dalam kondisi apapun seperti kondisi tak beroksigen/anoxia atau kadar oksigen rendah yang merupakan sifat habitat pasang surut perairan yang dangkal.

\section{c. Korelasi antara Kerapatan Lamun dengan Persentase Substrat}

Korelasi dilakukan untuk menganalisis hubungan antara dua variabel yang bersifat kuantitatif. Kedua variabel yang diuji adalah kerapatan lamun dan persentase substrat sand. Setelah di uji, nilai yang di dapatkan pada kedua stasiun adalah korelasi positif. Nilai korelasi antara kerapatan lamun dan persentase substrat sand pada stasiun 1 menunjukkan 0,9828 sedangkan koefisien determinasi $\left(\mathrm{R}^{2}\right)$ 0,966 menunjukkan kerapatan lamun dipengaruhi dari 96,6\% faktor internal dan 3,4\% faktor eksternal. Pada stasiun 2 nilai korelasinya 0,9823 sedangkan koefisien determinasi $\left(\mathrm{R}^{2}\right)$ 0,965 menunjukkan bahwa kerapatan lamun dipengaruhi $96,5 \%$ faktor internal dan 3,5\% faktor eksternal. Substrat sand disini berpengaruh pada kerapatan lamun namun pada stasiun 1 dan 2 terdapat faktor luar yang berpengaruh terhadap kerapatan lamun. Faktor luar disini diduga dari faktor lingkungan lain, seperti nilai $\mathrm{pH}$, arus, temperatur, atau salinitas perairan tersebut. Menurut Nybakken (1992), penyebaran horizontal lamun dipengaruhi oleh karakteristik substrat dan kondisi gerakan air (arus perairan).

\section{d. Faktor Lingkungan Perairan}

Suhu perairan di stasiun 1 yakni $31^{\circ} \mathrm{C}$, sedangkan pada stasiun 2 suhunya $32^{\circ} \mathrm{C}$. Menurut Hutomo (1985) suhu yang nomal untuk pertumbuhan lamun di perairan tropis berkisar antara $24-35^{\circ} \mathrm{C}$. Kecepatan arus pada saat pengamatan berkisar antara 0,04-0,06 m/s. Arus pada stasiun 2 lebih tenang dimungkinkan karena pada saat sampling stasiun 1 cuaca sedang mendung dan angin yang bertiup lebih kencang. Menurut Dahuri, et al (2001) pergerakan arus berpengaruh terhadap pertumbuhan lamun yang terkait dengan suplai unsur hara dan persediaan gas-gas terlarut yang dibutuhkan oleh lamun. Pengaruh pasang surut serta struktur substrat dapat mempengaruhi zonasi sebagian jenis lamun dan pertumbuhannya.

Kisaran nilai salinitas di Perairan Pantai Pancuran Belakang setiap stasiun masing-masing 33\%. Lamun dapat tumbuh baik dalam salinitas tersebut. Menurut Nybakken (1992) lamun hidup pada toleransi salinitas optimum 20-35\%. Nilai derajat keasaman $(\mathrm{pH})$ di lokasi penelitian 8 . Hal ini dapat disebabkan karena terdapat kandungan substrat gravel yang ada pada 2 stasiun tersebut. Gravel terdiri dari butiran pecahan karang mati, cangkang biota yang menyebabkan perairan lebih basa, karena pecahan karang mengandung zat kapur yang bersifat basa sehingga dapat mempengaruhi $\mathrm{pH}$ perairan. Kecerahan perairan pada kedua stasiun yaitu tak terhingga yang menunjukkan perairan cukup jernih dan cahaya matahari dapat masuk sampai dasar perairan. Kedalaman perairan pada lokasi penelitian tidak terlalu dalam kedalaman paling tinggi berada pada stasiun 2 yakni 1,5 meter. Kecerahan perairan berhubungan dengan kesuburan perairan yaitu berlangsungnya proses fotosintesis oleh lamun (Saputra, 2011).

Tipe substrat pada perairan pantai pancuran belakang sebagian besar terdiri atas sand (pasir) dan gravel (pecahan karang). Pada stasiun 1 komposisi sand (pasir) jauh lebih besar daripada komposisi gravel, silt dan clay yakni $89,05 \%$. Stasiun 2 komposisinya juga didominasi oleh sand (pasir). Kadar gravel pada stasiun 1 dan 2 berturut-turut adalah 9\% dan 17,80\% sedangkan kadar silt pada stasiun 1 dan 2 adalah 1,95\% dan $1 \%$. Komposisi clay pada kedua stasiun tersebut tidak ada $(0 \%)$. Peranan kedalaman substrat dalam stabilitas sedimen mencakup 2 hal yaitu sebagai pelindung tanaman dari arus air laut, dan tempat pengolahan dan 
pemasok nutrient. Klasifikasi tipe substrat seperti berbatu, berpasir, pasir berlumpur dan lumpur berpasir didasari oleh komposisi yang terkandung dalam substrat. Menurut Erftemeijer (1993) dalam Dahuri, et al (2001), amun biasanya tumbuh subur terutama pada daerah pasang surut terbuka serta perairan pantai yang dasarnya berupa lumpur, pasir, kerikil, dan patahan dengan karang mati. Kebutuhan substrat yang paling utama bagi pengembangan padang lamun adalah kedalaman sedimen yang cukup.

\section{Kesimpulan}

Berdasarkan hasil penelitian yang telah dilakukan maka dapat diambil kesimpulan terdapat 8 jenis spesies lamun yang ditemukan yaitu Thalassia hemperichii, Cymodocea rotundata, Syringodium isoetifolium, Halophilla minor, Enhalus acroides, Halophila ovalis, Cymodocea serrulata dan Halodule pinifolia. Stasiun 1 hanya ditemukan 6 jenis lamun saja, sedangkan pada stasiun 2 lamun yang ditemukan berjumlah 8 jenis. Jenis yang mendominasi dari kedua stasiun ini adalah Thalassia hemperichii, Cymodocea rotundata dan Syringodium isoetifolium. Kerapatan tertinggi lamun terdapat pada stasiun 2 yaitu 968 individu/ m, persentase tutupan tertinggi lamun terdapat pada stasiun 2 yaitu 11833 individu. Jenis sedimen yang ditemukan di Perairan Pantai Pancuran Belakang yakni gravel, sand dan silt. Jenis sedimen yang paling berpengaruh pada kepadatan lamun adalah sedimen sand (pasir).

\section{Ucapan Terima Kasih}

Penulis mengucapkan terimakasih kepada Prof. Dr. Ir. Agus Hartoko, M.Sc dan Dr. Ir. Suryanti, M.Pi. atas bimbingan dan arahannya dalam penyusunan jurnal ini.

\section{Daftar Pustaka}

Abroni, K. 2012. Analisa Spasial Distribusi Kerang Pisau (Solen grandis) dan Sebaran Sedimen dengan menggunakan Data Citra Satelit Landsat di Pantai Mangunan Kecamatan Pademawu Kabupaten Pamekasan, Madura. Program Sarjana, Universitas Diponegoro Semarang (Skripsi S1)

Azkab, M.H. 2006. Pertumbuhan dan Produksi Lamun Enhallus acroides di Rataan Terumbu di Pari Pulau Seribu. Balai Penelitian dan Pengembangan Oseanografi - LIPI. Jakarta

Brower, J.E,. Zar J. H. and Ende C, N. V. 1989. Field and Laboratory Method for General Ecology Fourth edition. Mc.Graw-Hill Publication. Boston, USA. Xi + 273p.

BTNKJ. 2012. Zonasi Taman Nasional Karimunjawa tahun 2012. http://tnkarimunjawa.dephut.go.id. Diakses pada tanggal 20 November 2013

Dahuri , R, J.Rais, S.P. Gintingt dan M.J Sitepu. 2001. Pengelolaan Sumberdaya Wilayah Pesisir dan Lautan secara Terpadu. Edisi Revisi. Pradnya Paramita. Jakarta

Hadi, S. 2004. Metodologi Research. Andi. Yogyakarta

Harianto. 2005. Inventarisasi Lamun Di Kepulauan Karimunjawa. Laporan Kegiatan Inventarisasi Lamun (Seagrass) Balai Taman Nasional Karimunjawa, Juli 2005. Karimunjawa

Hartoko, A. 2008. Modul Aplikasi Inderaja dan SIG Sumberdaya Wilayah Pantai. UNDIP Press, Semarang. ISBN : 978-979-704-892-1.

Kikuchi dan Peres J.M. ,1977. Customer ecology of seagrass beds. In seagrass Ecosystems. A Scientific Perspective, eds Mc. Roy P. \& Hellfferich, C. Marcel Dekker Inc. New York. Marine Sci. 4:147193

Kiswara, W. 2000. Struktur Komunitas Padang Lamun Perairan Indonesia. Hlm 54-61. In: Inventarisasi dan Evaluasi Potensi Laut Pesisir, Geologi, Kimia, Biologi dan Ekologi. Lembaga Ilmu Pengetahuan Indonesia

Nybakken JW. 1992. Biologi Laut Suatu Pendekatan Ekologis. Gramedia. Jakarta

Romimohtarto, K dan Juwana, S. 2001. Biologi Laut Ilmu Pengetahuan Tentang Biota Laut. Djambatan. Jakarta

Sugiyono, 2011. Metode Penelitian Kuantitatif, Kualitatif dan R \& D. Alfabeta. Bandung

Suliyanto. 2012. Analisis Korelasi. http:// management-unsoed.ac.id . Diakses pada tanggal 18 April 2013

WESTPAC. 2010. Field Guide to he Identification of East Asian, with Financial Support From Jappanese Founds in Trust for UNESCO 